Zootaxa 5087 (4): 600-600

https://www.mapress.com/zt/

Copyright (C) 2022 Magnolia Press

\section{Erratum}

https://doi.org/10.11646/zootaxa.5087.4.9

http://zoobank.org/urn:lsid:zoobank.org:pub:3F9213B4-DF90-4BF1-83D1-9D6FAB8BEB72
Z1500TAXA

ISSN 1175-5334 (online edition)

\title{
OLDRICH SYCHRA \& RICARDO L. PALMA (2021) A new species of Myrsidea (Insecta: Phthiraptera: Menoponidae) from Chile. Zootaxa, 5016: 441-447.
}

In the acknowledgements section the authors provided the incorrect format for the number of the project by which the work was supported. The correct format is "FVHE-Široký-2021ITA26" instead of "FVHE/Široký/ITA2021". 